\title{
A new type of colony in Silurian (upper Wenlock) retiolitid graptolite Spinograptus from Poland
}

Anna Kozłowska, Kinga Dobrowolska, and Denis E.B. Bates

Acta Palaeontologica Polonica 58 (1), 2013: 85-92 doi: http://dx.doi.org/10.4202/app.2011.0020

The new retiolitid species, Spinograptus tubothecalis, is described from the Colonograptus praedeubeli and $C$. deubeli biozones from two localities in Poland: a borehole on the East European Platform and the Holy Cross Mountains. This was a recovery phase after the severe Silurian Cyrtograptus lundgreni Event. The new species has a unique, previously undescribed form of finite rhabdosome. Unlike the species Spinograptus reticulolawsoni and S. lawsoni, in which the finite rhabdosomes taper distally, its rhabdosome is parallel-sided with the two distal thecae developed as isolated tubes without genicular processes, with a small appendix between them. The new species also has preserved membranes of the sicula, thecae and ancora sleeve, similar to a few species of Spinograptus from the lower Homerian. Spinograptus tubothecalis, like Spinograptus clathrospinosus and S. spinosus, has paired reticulofusellar genicular processes on the pre-thecal ventral orifices, similar to but shorter than thecal processes. Transverse rods, a rare character in post-Cyrtograptus lundgreni Event retiolitids occur in the new species in rudimentary form.

Key words: Graptoloidea, Retiolitidae, Spinograptus, finite colony, Silurian, Poland.

Anna Kozłowska [akd@twarda.pan.pl] and Kinga Dobrowolska [kdobrowolska@twarda.pan.pl ], Instytut Paleobiologii PAN, ul. Twarda 51/55, PL-00-818 Warszawa, Poland; Denis E.B. Bates [deb@aber.ac.uk], Institute of Geography and Earth Sciences, Aberystwyth University, Aberystwyth, Ceredigion SY23 3QQ, UK .

This is an open-access article distributed under the terms of the Creative Commons Attribution License (for details please see creativecommons.org), which permits unrestricted use, distribution, and reproduction in any medium, provided the original author and source are credited. 
Fof Full text $(971.4 \mathrm{kB})$ 